\title{
Business Students' Intentions to Change Majors Amid the Coronavirus Pandemic
}

\author{
Brian Trout \\ Millersville University
}

This study examines business students' intentions to change majors amid the coronavirus pandemic. Studies have explored factors associated with an undergraduate student's choice of major, but none have examined intentions to change major in the context of such a disruptive situation. Overall, students in this study did not intend to change majors in response to the coronavirus pandemic. Genuine interest in one's major was negatively associated with the intention to change major and sensitivity to social referents' opinions of changing majors was positively associated with intention to change major. Self-efficacy and perceptions of the financial implications surrounding the pandemic were not significantly associated with intention to change major.

Keywords: coronavirus higher education, business education, college major choices

\section{INTRODUCTION}

At the time of this writing, the coronavirus pandemic has led to an unprecedented shutdown in the United States which has had negative effects on consumer demand. Consequently, businesses are laying off workers to mitigate the financial damage. Record numbers of Americans are filing for unemployment due to coronavirus induced lay-offs. Economists are concerned that increased layoffs will continue to affect consumer spending, compounding business closures and the economic downturn. The government continues to combat these forces by increasing spending and welfare to small businesses and individual citizens.

How is this situation affecting students' intentions regarding their college majors? There are numerous studies that analyze factors that influence a student's choice of college major and a limited number of studies that explore the impact of economic downturns on choice of college major. However, no studies were found that examine students' intentions to change majors in the context of a situation like the coronavirus pandemic. This study will be of interest to higher education administrators as they allocate resources, employers as they consider the supply of business graduates, and business educators who advise students on majors and careers.

\section{LITERATURE REVIEW}

Factors that influence students' major and career choices have been examined by researchers in a variety of fields. Many have examined this topic through the Theory of Planned Behavior which contends intention is the best predictor of behavior. Much of the research in this area points to beliefs held by students 
which consequently influence their choices. Authors have categorized these factors in a variety of ways, but most can be classified broadly as external or internal factors. Some studies find extrinsic motivators to be significantly associated with career choices (Demagalhaes et al., 2011) while others find extrinsic motivators are not significantly related to career choices (Coe, 2016; $\mathrm{Ng}$ et al., 2017). Common external motivators discussed in literature are financial rewards, availability of employment, and social referents.

Individuals will experience different economic outcomes depending on what college major they choose (C. Kim et al., 2015). Degrees in STEM fields, business, and health have higher earnings, while degrees in humanities and education have lower earnings (C. Kim et al., 2015). The difference in earnings between college majors sometimes exceeds the difference in earnings between college graduates and those without college degrees (C. Kim et al., 2015). Accordingly, students are motivated by the financial returns associated with various majors and consequently choose majors associated with high incomes (Quadlin, 2017; Stivers \& Onifade, 2014). In addition to income, students also consider job availability when selecting college majors (Kumar \& Kumar, 2013; Quadlin, 2020). External parties also appear to heavily influence students' choices related to majors and careers. This factor is commonly described as "subjective norm" which is an individual's perception of whether people who are important in the individual's life (referents) favor a behavior (Felton et al., 1995). While a limited number of studies find external parties have an insignificant relation to career choices (Ng et al., 2017), most find social referents to be a major influence on students' major and career choices (Coe, 2016; Kumar \& Kumar, 2013; Porter \& Woolley, 2014).

Internal factors that may affect a student's major and career decisions include self-efficacy and genuine interest in the subject matter. Self-efficacy is confidence in one's own ability to achieve intended results (Ormrod, 2006). Kumar and Kumar (2013), using the Theory of Planned Behavior, concluded that a student's perceived aptitude is a significant factor in the choice of business major. Similarly, other studies have found self-efficacy to be positively related to joining certain business professions (Coe, 2016; James $\&$ Hill, 2009). Self-efficacy has also been found to be a deterrent to specific career pursuits. For example, Wen, Hao, and $\mathrm{Bu}$ (2015) found that perceived inability to succeed was negatively associated with intention to pursue the CPA examination.

Research consistently finds that genuine interest in a career is positively associated with students' career choices. Trout and Blazer (2019) found this to be the highest among all variables included in their model when examining students' intentions to pursue the CPA exam. Jackling and Calero (2006) also found that personal satisfaction with studies in accounting was the most significant predictor of intention to become an accountant. This is consistent with similar research (Beggs et al., 2008; Coe, 2016; Ng et al., 2017; Wen et al., 2015).

As the economic impacts of the coronavirus pandemic take effect, it is reasonable to assume students will take this information into account when declaring majors or examining their current majors and career goals. Business cycles affect college enrollment (Hershbein, 2012; Johnson, 2013). During declining labor markets, students are more likely to enroll in post-secondary education (Long, 2015). Bradley (2012) theorizes that several factors may increase enrollments during these periods: job seekers with only a high school degree find it more difficult to find jobs, the opportunity cost of leaving the job market to enroll in college is lower when wages are declining, and the difference in the financial return of investing in a college degree versus not increases during economic downturns.

As tuition and student debt continues to increase (Dwyer, 2018), economic outcomes associated with college majors are being prioritized by students. Naturally, the economic impacts of the coronavirus pandemic will make the financial outcomes of majors even more salient to students in their career and major decisions. Experiencing economic downturns affects individuals' risk preferences (Malmendier \& Nagel, 2011). This appears to manifest in students' choice of majors. Individuals exposed to higher unemployment rates during schooling years select majors that earn higher wages and have better employment prospects (Blom et al., 2015). Students are also more likely to select majors with higher wages and job security in periods after economic downturns (Bradley, 2012).

Current students switch majors when given new information that changes their expectations related to the investment value of their degrees (Arcidiacono et al., 2011; Wiswall \& Zafar, 2011). This is evidenced 
by Blom et al.'s, (2015) study which used the American Community Survey to examine the distribution of college majors for more than 50 birth cohorts. Long term earnings in each major was found to be the strongest predictor of "recession-induced" reallocation of majors. Blom et al. also find that economic downturns are correlated with a shift toward more challenging majors, even when earnings potential is held constant. The authors theorize that students may perceive that more challenging majors will help better insulate them from weak job markets and that students may be more sensitive to the signals their majors send to employers about their abilities.

\section{METHODOLOGY}

\section{Instrumentation}

Survey questions were informed by relevant literature and a pilot questionnaire using open-ended questions which asked students if (and why) they were considering changing their majors during the coronavirus pandemic. The questionnaire was designed to measure how various factors, in the context of the coronavirus pandemic, are impacting a student's intention to change major. Accordingly, the following measures were used:

- Demographic data: Gender, major, and class level

- Intention to change major: $1=$ strongly disagree to $5=$ strongly agree

- Four index variables were constructed using 16 statements where students rated their level agreement using a five-point Likert type scale ranging from $1=$ strongly disagree to $5=$ strongly agree:

- Financial consequences of the pandemic on their career

- Social referents' opinions about changing majors

- Genuine interest in one's major

- Self-efficacy in the face of the pandemic's possible negative outcomes

\section{Data Collection}

Data for this study were collected through an online survey released the last week of the Spring 2020 semester. The sample was drawn from undergraduate students enrolled in Managerial Accounting, Intermediate Accounting, and Personal Financial Planning. Students were offered a 5 percent increase on their final exam score for participating which equated to one-half of one percent of a student's final grade. The survey was anonymous. No names or unique identifiers were included on the instrument. Credit for completion of the survey was awarded to students through the University's learning management system where they selected "true" or "false" as a response to this statement: "I completed the Qualtrics survey about majors".

\section{Data Analysis}

Fifteen seniors were excluded from the dataset as these students were graduating at the end of the semester. Cronbach alpha statistics were computed to measure how closely related each group of questions were within each of the four index variables. All index variables were found to have acceptable alphas. Descriptive statistics regarding frequencies, percentages, and means of responses were computed for each variable. An ordered logistic regression was performed to assess the relationship between students' perception of financial implications, self-efficacy, genuine interest in college major, sensitivity to social referents, and gender to intention to change their college majors. A test of Parallel Lines was used to test this assumption of Proportional Odds. The results indicate this assumption is satisfied ( $\mathrm{p}=.476)$. Multicollinearity was tested using tolerance and variance inflation factors tests. The results of these tests on the independent variables are within acceptable ranges.

\section{Limitations}

This study focuses on students' intentions related to changing majors amid the coronavirus pandemic. While studies show intention can predict actual behavior, this is not always the case (Sheeran, Webb, \& 
Gollwitzer, 2005). The potential for social desirability bias also exists. Students could believe that the researcher would not favor changing their business majors. Students in this study were not randomly selected. Only students enrolled in select business classes were offered the opportunity to participate. The sample was drawn from one university; therefore, generalizing results should be done with caution.

\section{RESULTS}

\section{Demographics}

The sample was comprised of 101 undergraduate business students with a mean age of 20.33 years (SD $=1.87$ years). Table 1 shows frequencies and percentages for gender, major, and class level.

TABLE 1

GENDER, MAJOR, AND CLASS LEVEL DATA

\begin{tabular}{llcc}
\hline \multicolumn{1}{c}{} & Frequency & Percent \\
\hline Gender & & \\
& Males & 57 & 56.44 \\
& Females & 44 & 43.56 \\
Other & 0 & 0.00 \\
Major & & \\
& Accounting & 31 & 30.69 \\
& Finance & 12 & 11.88 \\
Marketing & 12 & 11.88 \\
Management & 22 & 21.78 \\
& International & 5 & 4.95 \\
$\quad$ General Business & 19 & 18.81 \\
Class Level & & \\
$\quad$ Freshmen & 20 & 19.80 \\
Sophomore & 49 & 48.51 \\
Junior & 32 & 31.68 \\
\hline
\end{tabular}

\section{Descriptive Statistics}

Index variables were created from individual questions to construct four explanatory variables measured via a five-point Likert type scale. A student's intention to change major was also measured using a five-point Likert type scale with 1 representing strongly disagree to 5 representing strongly agree. Means and standard deviations for these variables are presented in Table 2.

TABLE 2

DESCRIPTIVE STATISTICS

\begin{tabular}{lcc}
\hline & $\mathrm{M}$ & $\mathrm{SD}$ \\
\hline Intention to change major & 1.69 & 0.95 \\
Financial considerations & 2.77 & 0.84 \\
Self-efficacy & 4.29 & 0.78 \\
Genuine interest in major & 4.30 & 0.76 \\
Social influence & 2.14 & 0.82 \\
\hline
\end{tabular}

\section{Inferential Statistics}

An ordered logistic regression was performed to assess the relationship between the independent variables and intention to change their college majors. A chi-square test indicates that there is a significant 
improvement in fit of the model over the null model $\left[\chi^{2}(5)=32.447, \mathrm{p}<.001\right]$. The Pearson chi-square test $\left[\chi^{2}(379)=327.691, p=.973\right]$ and the deviance test $\left[\chi^{2}(379)=192.242, p=1.00\right]$ were both non-significant. This suggests a good model fit. The Cox and Snell $\mathrm{R}^{2}$ and the Nagelkerke $\mathrm{R}^{2}$ can be interpreted as the percentage variation in the dependent variable which is explained by the independent variables (Pearson, 2010). The explanatory variables included in this study account for approximately 27.5 to 30.7 percent of the variation in a student's intention to change majors.

There was no significant association between gender, financial considerations, and self-efficacy and a student's intention to change major. However, two explanatory variables showed significant associations with intention to change major: genuine interest and social influence. Genuine interest in major was a significant negative predictor of intention to change major. For every one unit increase on the genuine interest scale, there is a predicted decrease of .81 in the log odds of a student being in a higher level of intention to change major. The odds ratio of 0.445 (95\% CI, .232 to .850$)$, Wald $\chi^{2}(1)=6.001, \mathrm{p}<.05$ indicates that for every one unit increase on the genuine interest scale, a student is .445 times less likely to be in a higher level of intention to change major, while controlling for other independent variables. Social influence was a significant positive predictor of intention to change major. For every one unit increase on the genuine interest scale, there is a predicted increase of 1.097 in the log odds of a student being in a higher level of intention to change major. The odds ratio of $2.995\left(95 \%\right.$ CI, 1.589 to 5.643), Wald $\chi^{2}(1)=11.509$, $\mathrm{p}<.01$ indicates that for every one unit increase on the social influence scale, a student is 2.995 times more likely to be in a higher category of intention to change major, while controlling for other independent variables. The results are presented Table 3 .

TABLE 3 ORDERED LOGISTIC REGRESSION RESULTS

\begin{tabular}{lccccc}
\hline & $\mathrm{B}$ & $\mathrm{SE} \mathrm{B}$ & Wald & $\mathrm{p}$ & OR \\
\hline Financial considerations & 0.481 & 0.278 & 2.997 & 0.083 & 1.618 \\
Self-efficacy & -0.020 & 0.316 & 0.004 & 0.950 & 0.980 \\
Genuine interest in major & -0.810 & 0.331 & 6.001 & 0.014 & 0.445 \\
Social influence & 1.097 & 0.323 & 11.509 & 0.001 & 2.995 \\
Gender & -0.828 & 0.438 & 3.565 & 0.059 & 0.437 \\
\hline
\end{tabular}

\section{DISCUSSION}

The mean rating of agreement with "I am considering changing my major, business concentration or minor" was lower than expected, considering the timing and context of the survey. As Dwyer (2018) notes, tuition and student debt are being prioritized by students. One of the consequences of changing majors is the additional time and costs required to complete graduation requirements. As one student put it "I'm sticking with my major because I spent so much time and money on this major and this college". However, most students cited personal interests and the post-graduation job market as support for their low degree of interest in changing majors at this moment in time.

Genuine interest in one's major was found to be significantly negatively related to a student's intention to change major. In other words, a higher degree of genuine interest in a student's current major is associated with a lower likelihood of switching to another major while controlling for other variables. Research shows that intrinsic motivation is typically a significant factor in students' career choices (Beggs \& Bantham, 2008; D. Kim et al., 2002; Ng et al., 2017). This also applies to persisting in or changing a major. One student said, "I am sticking with my current major because I am truly interested in this path". Another reported "I am not considering a change in major because I enjoy accounting". Conklin, Dahling, and Garcia (2013) found that for students to remain committed to a major, they must perceive they belong or identify with a major. Students in this study report they are genuinely interested in their current business major, believe it fits who they are, believe a career in the major's field will be personally fulfilling, and believe their major will help them find a job that they will love. A question for future research is "Are students' 
perceptions of careers in their major's field accurate?" Firmin and MacKillop (2008) find students originally select majors with a lack of knowledge about the field and associated careers. Dhanfu Elston, VP of Complete College America, asserts that students make uninformed college major decisions, often based on other parties' input rather than relying on concrete information about the labor market (Marcus, 2018).

Overall, students reported that they disagree that experts, family members, employers, and professors and teachers would recommend changing majors in response to the coronavirus pandemic. This variable demonstrated the strongest relationship to a student's intention to change major. For every one unit increase in the Likert scale, a student is 2.995 times more likely to change majors. These results are consistent with studies that show subjective norm as a positive influence on students' choice of major (Kumar \& Kumar, 2013; Porter \& Woolley, 2014). The results should remind educators that they heavily influence students' choices of majors and careers. Educators must stay current on the roles and careers that today's college majors will lead to if they are to help students make informed decisions. In addition, educators must be intentional about transferring this knowledge. The stakes are high. Roese and Summerville (2005) found that making wrong educational choices was the leading reported life-regret in their studies on regrets. A survey of 90,000 interviewees conducted by Gallup found that 36 percent of adults in the U.S. would change their field of study (Marken \& Auter, 2017).

Perception of negative economic consequences of the pandemic were not significantly associated with intention to change major. Noteworthy are students' perceptions regarding the financial consequences of the coronavirus pandemic on their long-term job prospects, lifetime earnings, immediate job prospects, and general economic conditions. Students' perceptions of these potential consequences was significantly lower than 3.0 (neutral). Students in this study generally disagree that the coronavirus pandemic will have unfavorable consequences on their finances and job prospects.

While existing studies show students change majors in response to economic downturns (Blom et al., 2015), there are no studies that solely concentrate on business students' proclivity to change majors during situations akin to the coronavirus pandemic. Blom et al. (2015) study showed that students are more likely to change their majors to those that provide favorable economic outcomes. Degrees in business generally have higher earnings than degrees in humanities and education (C. Kim et al., 2015) and research shows that students motivated by these factors choose their majors accordingly (Kumar \& Kumar, 2013; Quadlin, 2017, 2020; Stivers \& Onifade, 2014). Therefore, it is reasonable to assume that the students in this study may believe that their majors have more favorable income and job stability prospects in the post-pandemic world compared to other majors. Student responses to open-ended comments support this theory:

○ "If anything, this pandemic has made me feel more secure in my decision to get a degree in accounting and have a steady salary"

- "I think Covid-19 has impacted my intentions because I can see that if something extreme happens, I know I will still have a job"

Considering the timing of this study, it may be fair to infer that students do not perceive a significantly unfavorable economic outcome on their income and job security because there has not been sufficient time or information to support such a decision. One student said, "I think this is not a time to reexamine (majors) because there is too much happening around the world". Another student pointed to limited knowledge about possible consequences on the job market: "I'm a little worried about a recession but I'm not sure how much of an effect it will have. I was only 9 during the 2008 crash so I don't really have any perspective what the job market is like". Students are certainly not acting impulsively which is generally prudent. Marade and Brinthaupt (2018) note that acting on impulse can have negative impacts on educational goals, especially when selecting a major.

A student's degree of self-efficacy in the context of the coronavirus was not significantly related to intention to change major. Conklin et al. (2013) finds that one of the factors necessary for students to remain committed to a major is the perception of positive results. Students generally agreed that they will be able to overcome career challenges presented by the pandemic and believe in their abilities to succeed regardless of external circumstances like the pandemic. When students feel confident in their ability to complete their current major and demonstrate certainty in their chosen profession, they are less likely to change majors (Drysdale, 2015). 
The level of self-efficacy among students may be an area for future study. This variable was higher than expected but it is not uncommon for individuals to overestimate their abilities (Kennedy et al., 2002). Some authors are concerned about this overestimation as it relates to the generational cohort examined in this study. Schroth (2019) contends that Generation Z employees often have unrealistic expectations about the enjoyability of their careers. This author provides evidence that the overprotected upbringing of this generation has compromised their ability to successfully navigate challenges in the workplace and life. Schroth (2019) finds that this can lead to a fixed mindset where these individuals are fearful of showing they are not competent because they see abilities as fixed (compared to a growth mindset). Other authors point out that Gen $\mathrm{Z}$ is entering adulthood with less work experience than prior generations (Fry \& Parker, 2018) and their perceptions about career demands have not been challenged (Harder et al., 2015).

In conclusion, this study finds business students are not inclined to change majors in response to the coronavirus pandemic. Genuine interest in one's major was significantly negatively associated with intention to change major while sensitivity to social referents' opinions was significantly positively associated with intention to change major. Educators should be conscientious of their influential roles and diligent in acquiring and sharing information about career outcomes associated with different business majors. Student responses indicate that their intrinsic interest in their major remains high amid the pandemic and they do not perceive that social referents would recommend changing their major in response to this crisis. Gender, financial consequences of the pandemic, and self-efficacy were not significantly associated with a student's intention to change major. Generally, these business students do not perceive that negative financial implications from the coronavirus pandemic will come to bear on their income or job stability. They also report that they are confident in their abilities to succeed regardless of what the coronavirus pandemic may bring. This study will be of interest to higher education administrators as they allocate resources, employers as they consider the supply of business graduates, and business educators who advise students on majors and careers.

\section{REFERENCES}

Arcidiacono, P., Hotz, J., \& Kang, S. (2011). College major choices using elicited measures of expectations and counterfactuals (No. 15729). Retrieved from https://www.nber.org/papers/w15729

Beggs, J., \& Bantham, J. (2008). Distinguishing the factors influencing college students' choice of major. College Student Journal, 42(2), 381-394.

Beggs, J., Bantham, J., \& Taylor, S. (2008). Distinguishing the factors influencing college students' choice of major. College Student Journal, 42(2), 381-394.

Blom, E., Cadena, B., \& Keys, B. (2015). Investment over the Business Cycle: Insights from College Major Choice. IZA Discussion Paper, 9167. Retrieved from http://ftp.iza.org/dp9167.pdf

Bradley, E. (2012). The effect of business cycle on freshmen major choice. Retrieved from https://ideas.repec.org/p/pra/mprapa/42412.html

Coe, M. (2016, August). Factors that influence a student's intention to sit for the CPA exam. The CPA Journal, pp. 18-20.

Conklin, A., Dahling, J., \& Garcia, P. (2013). Linking affective commitment, career efficacy, and outcome expectations: A test of social cognitive career theory. Journal of Career Development, $40,68-83$.

Demagalhaes, R., Wilde, H., \& Fitzgerald, L. (2011). Factors affecting accounting students' employment choices: A comparison of students' and practitioners' views. Journal of Higher Education Theory and Practice, 11(2), 32-40.

Drysdale, M. (2015). How often do they change their minds and does work-integrated learning play a role? An examination of "major changers" and career certainty in higher education. Asia-Pacific Journal of Cooperative Education, 16(2), 145-152.

Dwyer, R. (2018). Credit, debt, and inequality. Annual Review of Sociology, 44, 237-261. 
Felton, S., Dimnik, T., \& Northey, M. (1995). A theory of reasoned action model of the chartered accountant career choice. Journal of Accounting Education, 13(1), 1-19.

Firmin, M., \& MacKillop, L. (2008). Frequent major changing: Extrinsic and intrinsic factors. $N A C-A D A$ Journal, 2, 5-13.

Fry, R., \& Parker, K. (2018, November 15). Early benchmarks show "post-millennials" on track to be most diverse, best-educated generation yet. Pew Research Center. Retrieved from https://www.pewsocialtrends.org/2018/11/15/early-benchmarks-show-post-millennials-on-trackto-be-most-diverse-best-educated-generation-yet/

Harder, J., Czyzewski, A., \& Sherwood, A. (2015). Student self-efficacy in a chosen business career path: The influence of cognitive style. College Student Journal, 49(3), 341-354.

Hershbein, B. (2012). Graduating high school in a recession: Work, education, and home production. The BE Journal of Economic Analysis \& Policy, 12(1).

James, K., \& Hill, C. (2009). Race and the development of career interest in accounting. Journal of Accounting Education, 27(4), 210-222.

Johnson, M. (2013). The impact of business cycle fluctuations on graduate school enrollment. Economics of Education Review, 34, 122-134.

Kennedy, E., Lawton, L., \& Plumlee, E.L. (2002). Blissful ignorance: The problem of unrecognized incompetence and academic performance. Journal of Marketing Education, 24(3), 243-252.

Kim, C., Tamborini, C., \& Sakamoto, A. (2015). Field of study in college and lifetime earnings in the United States. Sociology of Education, 88, 320-339.

Kim, D., Markham, F.S., \& Cangelosi, J. (2002). Why students pursue the business degree: A comparison of business majors across universities. Journal of Education for Business, 78(1), 28-32.

Kumar, A., \& Kumar, P. (2013). An examination of factors influencing students' selection of business majors using TRA framework. Decision Sciences Journal of Innovative Education, 11(1), $77-$ 105.

Long, B. (2015). The financial crisis and college enrollment: How have students and their families responded? In How the financial crisis and great recession affected higher education (pp. 209233). University of Chicago Press. Retrieved from https://www.nber.org/chapters/c12862.pdf

Malmendier, U., \& Nagel, S. (2011). Depression babies: Do macroeconomic expectations affect risk taking? Quarterly Journal of Economics, 126(1).

Marade, A., \& Brinthaupt, T. (2018). Good and bad reasons for changing a college major: A comparison of student and faculty views. Education, 138(4), 323-334.

Marcus, J. (2018, December 7). Switching majors is adding time and tuition to the already high cost of college. The Hechinger Report. Retrieved from https://hechingerreport.org/switching-majors-isadding-time-and-tuition-to-the-already-high-cost-of-college/

Marken, S., \& Auter, Z. (2017). Half of U.S. adults would change at least one education decision. Gallup. Retrieved from https://news.gallup.com/poll/211529/half-adults-change-least-one-educationdecision.aspx

Ng, Y., Lai, S., Su, Z., Yap, J., Teoh, H., \& Lee, H. (2017). Factors influencing accounting students' career paths. Journal of Management Development, 36(3), 319-329.

Ormrod, J. (2006). Educational psychology: Developing learners (5th ed.). Pearson/Merrill Prentice Hall.

Porter, J., \& Woolley, D. (2014). An examination of the factors affecting students' decision to major in accounting. International Journal of Accounting and Taxation, 2(4), 1-22.

Quadlin, N. (2017). Funding sources, family income, and fields of study in college. Social Forces, 96, 91-120.

Quadlin, N. (2020). From major preferences to major choices: Gender and logics of major choice. Sociology of Education, 93(2), 91-109.

Roese, N., \& Summerville, A. (2005). What we regret the most...and why. Personality and Social Psychology Bulletin, 9, 1273-1285.

Schroth, H. (2019). Are you ready for Gen Z in the workplace. California Management Review, 61(3), 518. 
Stivers, B., \& Onifade, E. (2014). Students perceptions of introductory accounting and the accounting profession. Academy of Educational Leadership Journal, 18(3), 49-60.

Trout, B., \& Blazer, E. (2019). What motivates students to take the CPA exam? Pennsylvania Economic Association Conference Proceedings, pp. 383-394.

Wen, L., Hao, Q., \& Bu, D. (2015). Understanding the intentions of accounting students in China to pursue certified public accountant designation. Accounting Education, 24(4), 341-359. https://doi.org/10.1080/09639284.2015.1051561

Wiswall, M., \& Zafar, B. (2011). Belief updating among college students: Evidence from experimental variation in information. Retrieved from https://www.newyorkfed.org/medialibrary/media/research/staff_reports/sr516.html 